\title{
Tres gongorinos novohispanos del siglo XVIII
}

\author{
Martha Lilia Tenorio
}

En Nueva España la influencia de Góngora se extendió a lo largo de todo el siglo XVIII, pero se manifestó en modalidades diferentes a las adoptadas en el siglo XVII. De esas modalidades son representativos los tres poetas que aquí se estudian: José Gil Ramírez, Miguel de Reina Zeballos y Francisco Ruiz de León.

Palabras Clave: Francisco Ruiz de León, José Gil Ramírez, Miguel de Reina Zeballos, Poesía novohispana siglo XVIII, Góngora.

Góngora's influence in New Spain was maintained throughout the Eighteenth Century, but in different ways than those acquired in the Seventeenth Century. The three poets that represent these new forms are José Gil Ramírez, Miguel de Reina Zeballos and Francisco Ruiz de León, whose works are here analyzed.

Keywords: Francisco Ruiz de León, José Gil Ramírez, Miguel de Reina Zeballos, New Spain poetry from 18th century, Góngora.

Fecha de recepción: 7 de marzo de 2011

Fecha de aceptación: 25 de abril de 2011 


\author{
Martha Lilia Tenorio \\ El Colegio de México
}

\title{
Tres gongorinos novohispanos del siglo XVIII
}

\section{Para “mi profe”, Antonio Alatorre, siempre}

Mucho se ha hablado del influjo de Góngora en la poesía novohispana del siglo XVII, y poco de cómo se extendió hacia el siglo XVIII e, incluso, hacia los comienzos del XIX. ${ }^{1}$ El siglo XVIII fue una continuación, aunque renovada, de la febril actividad lírica del XVII. Siguieron los certámenes y arcos triunfales, tan prototípicos del "virreinato de filigrana" (en palabras de Alfonso Reyes), pero pronto empezaron a perder sus "gongóricos" acentos. Tengo la impresión de que, desde las primeras décadas del siglo XVIII, el gongorismo que había caracterizado la lírica del XVII comenzó a dejar de ser la opción de los certámenes, aunque siguió siendo la elección individual de varios autores (por ejemplo, Francisco de Solís y Alcázar, Diego Ambrosio de Orcolaga, Lucas Fernández del Rincón, Juan Antonio de Segura - y los poetas de su Academia_-, además de los tres autores que aquí analizaré [Tenorio, Poesía novohispana. Antología,

${ }^{1}$ Como se demuestra en la traducción del padre Francisco Xavier Alegre del épodo "Beatus ille..." de Horacio, publicada en el Diario de México en 1806. Estudio este fenómeno en El gongorismo en Nueva España. Ensayo de restitución (en prensa). 
t. 2]). La sociedad letrada, la elite cultural, se fue alejando (no sin resistencias) de la lengua gongorina; quizás, siempre atenta a las modas peninsulares, advirtió pronto la reacción anti-barroca que empezaba a gestarse y, creo, contra sus propias convicciones estéticas, intentó otros derroteros líricos. Sin embargo, "donde hubo fuego, cenizas quedan", y en este siglo vio la luz la obra de tres poetas dignos de tomarse en cuenta en una historia del gongorismo novohispano: José Gil Ramírez, Miguel de Reina Zeballos y Francisco Ruiz de León.

En 1714 publicó fray José Gil Ramírez su Esfera mexicana, descripción y explicación del arco en honor al nacimiento del infante Felipe Pedro. En una de las paredes se representaba al rey Felipe V y a su esposa, María Luisa Gabriela, con el infante en brazos; bajo el lienzo se encontraba un soneto con este primer cuarteto:

Este regio pimpollo dominante, ardiendo nieves y nevando ardores, es Ethna vegetable entre las flores, que oculta en viva nieve ardor fragante (f. $21 \mathrm{v}$ ).

Para empezar notemos (no importa la brevedad de la cita, pues puede confirmarse en los siguientes pasajes) la ausencia de hipérbatos. Sin exagerar podríamos decir que prácticamente toda la lírica de la segunda mitad del siglo XVII recurrió al hipérbaton (en su mayor parte, mal entendido, reduciéndolo a un burdo desorden sintáctico) como ostentosa prueba de su adscripción a la poesía culta, y por poesía culta no se entendía otra cosa que la de Góngora.

Otro procedimiento común, pero no explotado con el abuso del hipérbaton, fue el trueque de epítetos o hipálages, recurso visible por medio del cual, con relativa facilidad, el poeta ostentaba las maneras del maestro y su filiación. A pesar de la lexicalización del procedimiento, la figura ("ardiendo nieves 
y nevando ardores") confiere todavía a estos versos algo de su primigenia eficacia lírica.

Más adelante, en el pasaje en que las ciudades de Nueva España alaban al recién nacido, se presenta Mérida: "cabeza ilustre de Campeche, no tanto conocida por el codiciado fructo de la cera, que vinculó el cielo a sus países, quanto por este epígraphe, que mostraba su amante incendio" (f. 23r). Nótese, incluso aquí, en la simple presentación de la ciudad, el uso de vincular como cultismo, en el sentido forense empleado por Góngora; ${ }^{2}$ pero veamos la exposición de los dones de Mérida:

...Esta, pues, opulenta

noble ciudad, a vuestro culto atenta, os rinde, heroyco dueño, de su crecido amor corto diseño, con afecto leal y decoroso, un tan sagrado don como precioso, compuesto de destellos que Flora en granos athesora bellos y en fragatas de rosa comercia con el cielo venturosa por occéanos de púrpura y de nieve que a blandos soplos el Favonio mueve, y, aveja susurrante, pyrata alado en piélago fragante, o le roba o le liba con ambiciossa sed, con ansia viva, para hazer de este robo, argumentosa,

${ }^{2}$ Así explica Jammes, en su edición de las Soledades, el uso del término en el verso 931 de la Soledad I ("Entre opulencias y necesidades, / medianías vinculen competentes / a vuestros descendientes..."): "Vinculen: palabra forense. La vinculación, utilizada sobre todo para constituir mayorazgos, era la creación de un patrimonio inalienable, que se había de transmitir íntegro a los descendientes sucesivos (a quienes iba vinculado), para que se perpetuara en una rama de una familia el nivel económico y social de su fundador" (388). 
ya dulçe miel, ya cera luminosa

que en llama refulgente

arde en las aras culto reverente.

Cera, en fin, os dedica,

en otra mejorada que fabrica

dulçe aveja oficiosa,

en la fe de su pecho fervorosa

que, a vuestro culto y a su fama,

eterna aliente su implacable llama. (f. 28r-v)

Desde siempre la literatura ha sido el espacio para la expresión del asombro provocado por las abejas y su miel. Este diminuto animal, que vive en sociedad, bajo leyes complicadas, y ejecuta en la sombra trabajos prodigiosos, atrajo con asombrosa frecuencia la curiosidad de propios y extraños. Aristóteles, Catón, Varrón, Columela y, por supuesto, Plinio, quien le dedica los parágrafos 11 a 70 del libro IX de su Historia natural:

Pero entre todos éstos, tienen la primacía las abejas y, en estricta justicia, nuestra especial admiración, pues son los únicos animales de este género [los insectos] nacidos en interés de los hombres. Reúnen la miel y un jugo dulcísimo, ligerísimo y salubérrimo, fabrican panales y cera para mil cosas de la vida, soportan el trabajo, ejecutan su tarea, tienen su república...

Y qué decir del pasaje que les dedica el "naturalista a lo divino" que fue fray Luis de Granada (Introducción al Símbolo de la Fe. Primera parte, caps. 19 y 20), obviamente, a partir de las noticias de Plinio, pero hay que ver con qué deleite, detenimiento y auténtico amor habla de estos "animalillos":

Pregunto, pues, agora ¿qué instrumento tiene este animalillo tan pequeño sino unos pecillos tan delgados como hilos, y un aguijoncillo tan delgado como ellos? Pues ¿cómo con tan fla- 
cos instrumentos y sin más cocimientos ni fuego hacen esta tan dulce conserva y esta transformación de flores en un tan suave licor de miel, a veces amarillo como cera, a veces blanco como la nieve, y esto no en pequeña cantidad (cual se podría esperar de un animalillo tan pequeño), sino en tanta cuantidad, cuanta se saca en buen tiempo de una colmena? ¿Quién enseñó a este animal a hacer esta alquimia, que es convertir una sustancia en otra diferente? (365).

A la miel, considerada don divino (por creer los antiguos que era un rocío del cielo que luego recogían las abejas, o porque, según el mito, Júpiter se alimentó con ella en Creta) se le han dedicado versos hermosísimos, desde aquellos primeros del libro IV de las Geórgicas: "Protinus aërii mellis caelestia dona / exsequar..." ('Ahora cantaré el don divino de la miel que viene del cielo...', v. 1), hasta aquella prodigiosa octava del Polifemo:

Sudando néctar, lambicando olores, senos que ignora aun la golosa cabra corchos me guardan, más que abeja flores liba inquïeta, ingenïosa labra; troncos me ofrecen, árboles mayores, cuyos enjambres, o el abril los abra o los desate el mayo, ámbar distilan y en ruecas de oro rayos del sol hilan. (vv. 393-400)

Con todo derecho, el pasaje de Gil Ramírez se inserta en esta tradición: la miel, "don tan sagrado como precioso", formada - como pensaban los antiguos - a partir de las gotas de rocío, "destellos que Flora en granos athesora bellos", las imágenes del intercambio comercial entre el cielo y la tierra "en fragatas de rosa", de la abeja "cual pyrata alado" en "occéanos de púrpura y de nieve", que — como pirata que se respeta - ambiciosa, ansiosa, ávida, roba esos tesoros que luego, artificiosa, 
cuidadosa (afortunado cultismo el argumentosa) convierte en "dulce miel" y "cera luminosa":

Essa que labra aveja exploradora, en piélago de flores, buzo errante de las perlas que grana limpia aurora en róseo nácar de esplendor fragante, la luz alienta que la noche dora, mas la acaba al rigor de lo flamante. La que en mi pecho os doy, vital alienta eterna llama que el amor fomenta. (f. 23r-v) ${ }^{3}$

La elaboración de esta octava sobre la cera que arde como el pecho de Nueva España por el infante Felipe Pedro, en sus imágenes, factura y léxico debe no poco al cordobés: Mérida, pues, ofrece su mayor riqueza, "el codiciado fruto de la cera", descrito con el primor con que Góngora suele deleitarse cuando presenta los pequeños tesoros de la naturaleza.

Gil Ramírez refrenda esta particular lección gongorina en la presentación de la riqueza ofrecida por Oaxaca, a saber, la "púrpura indiana" o cochinilla: "Este a quien presta el cielo generoso / rústica cuna en su rosado oriente, / múrice occiduo de valor precioso, / a el tirio y el sidón émulo ardiente..." (f. 23v). Véase el primoroso y espacioso esmero de su descripción:
Púrpura indiana, noble quanto rica, a quien bárbara planta dio pungente grosera cuna en su rosado oriente: emulación de aquella,

${ }^{3}$ Cfr. aquí, otra vez, a fray Luis de Granada: "Pues ¿cuán provechosa es también la cera que ellas fabrican junto con la miel? Con ella resplandecen los altares, con ella se autorizan las procesiones, della se sirven las cofradías, con ella se celebran los enterramientos, y con ella se adornan las mesas de los grandes señores y de los reyes" (Introducción al Símbolo de la Fe, 353). 
rica en su precio y en su aspecto bella, que, en avara garganta, infiel retira un pezesillo que las ondas gira, y Alcides descubrió de amores ciego, a la luz que le dio su obscuro fuego, honra de Tyro hermosa, ardiente, vital sangre generosa, que a su patria dio fama y al imperio en divisas roja llama. (f. 28v)

La cochinilla (su nombre náhuatl es nocheztli) es un insecto que se cría en los tallos de las tuneras o nopales, de ahí el verso "a quien bárbara planta dio pungente", con el cultismo pungente, 'que punza'; de él se extrae un tinte grana, émulo (imitador/ rival) de la púrpura del múrice. La definición de púrpura en el Diccionario de Autoridades aclara los versos "que, en avara garganta, infiel retira / un pezesillo que las ondas gira": "pescado de concha retorcida como la del caracol, dentro de cuya garganta se halla aquel precioso liquor roxo...". Lo que sigue es una alusión a los amores de Hércules y Deyanira, y al trágico final del héroe a causa de la capa teñida con la sangre del centauro Neso (de ahí la relación con púrpura).

Más adelante se presenta la abundancia natural de Durango, con imágenes e hipérboles que evocan claramente las riquezas de Polifemo:

Reyno tal, que sus términos distantes hasta oy no han visto linces caminantes, inundando de nieve desata en plata lo que en copos bebe; cuyas campañas bellas, aradas todas de vivientes huellas, muestran la multitud de los ganados, langostas de sus selvas y sus prados, 
que, qual secos estíos,

agotan fuentes y consumen ríos;

sus cumbres pisa montaraz temido,

desnudo de piedad, de horror vestido,

el bárbaro caribe que, inhumano,

duro al afán, quanto al rigor tirano,

armado de fiereza

embaraza el regalo y la riqueza. (f. 29r)

Recordemos a Polifemo ostentando sus riquezas ante la bella y esquiva Galatea:

Pastor soy, mas tan rico de ganados, que los valles impido, más vacíos, los cerros desparezco, levantados, y los caudales seco, de los ríos:

no los que, de sus ubres desatados

o derivados de los ojos míos, leche corren y lágrimas, que iguales en número a mis bienes son mis males. (vv. 385-392)

El principio de la hipérbole es el mismo en los dos poetas y está enraizado en una larga tradición (por lo menos desde el Polifemo de Ovidio en sus Metamorfosis, libro XIII). También los recursos son parecidos; Góngora expresa la abundancia del ganado a través de dos imágenes: los montes, aun los más altos, son "borrados" por las ovejas que ocupan el terreno, y los ríos se quedan sin agua, consumidos por los animales. Gil Ramírez presenta la abundancia de ganados por medio de la imagen de un campo "arado" por "vivientes huellas" (el continuo pastar de los animales), tantas que, cual plaga de "langostas", secan los ríos al saciar su sed. Finalmente, así como Polifemo "impide" (estorba, ocupa) los valles con sus ganados, aquí el cazador "embaraza" con su fiereza las cumbres, fiereza descrita tam- 
bién a lo Góngora: "el bárbaro caribe" (que recuerda los "caribes crueles" de las décimas "Nos os diremos como al Cid...", v. 100), "desnudo de piedad", como la caverna de Polifemo, expresión que Gil Ramírez complementa con una afortunada construcción quiásmica: "de horror vestido".

También rico, pero él en viñedos, Durango ofrece su fruto:

\author{
Aquí el cielo fecunda \\ valles que en ubas, liberal, inunda, \\ cuya sangre a Lyeo, \\ imán purpúreo, le llamó el deseo; \\ el fructo de ésta opimo \\ en esse fiel os da dulçe razimo, \\ cuya sangre encendida \\ va, quando corre, mucho más lucida... (f. 29r-v)
}

Cosa aún más digna de atención son las muchas pinceladas gongorinas de la relación en prosa. Sobre los modos gongorinos en la prosa, Antonio Carreira señala (refiriéndose concretamente a los prólogos del Triunfo parténico):

Sigüenza nos habla de "jeroglíficos de tanto garbo, que con silencio vocalísimo cantaban epinicios al triunfo parténico" (Triunfo Parténico, 86). ¿De dónde sale ese "silencio vocalísimo"? Pues del soneto gongorino "Las que a otro negó piedras oriente", dedicado al conde de Villamediana, que guarda en su camarín cuanto "pincel valiente... / ...parlero / silencio en sus vocales tintas miente". Lo que en el poema está justificado, lo está mucho menos en la prosa donde la cita se incrusta, porque le confiere un espesor metafórico inusual. En otra ocasión, el mismo Sigüenza dice de la plebe "que en semejantes acontecimientos, más que vistiéndose la garnacha de Licurgo, empuñando la vara de Aristarco lo advierte todo", ingenuo homenaje a La Tisbe gongorina: "La vez que vistió Paris / la garnacha de 
Licurgo" (vv. 77-78) ("Pros y contras de la influencia gongorina...", 347-364).

En el texto de Gil Ramírez, además de citas exactas de Góngora ( $c f r$. infra), encontramos una manera expresiva influida por el cordobés; manera que, en efecto, confiere al texto una densidad metafórica novedosa. Véase, por ejemplo, esta plástica descripción del atardecer, iluminado por los juegos pirotécnicos, cuyo fuego va en consonancia con el ardor de los corazones novohispanos:

Acabó el día, pero no la luz, pues apenas el sol anocheció, quando amaneció la noche, artificioso hipálage que sólo la lealtad pudo hazerle, desmintiendo a las estrellas, ya [en] el afectado zenit de las abrasadas luminarias, donde hasta los troncos ardieron mariposas en llamas de afecto, y ya en los prevenidos fuegos, donde los errantes cometas, que, tal vez, fueron infausto agüero a los cetros, ésta fueron feliz auspicio a la corona (f. 32v).

Curioso el juego metafórico: "el sol anocheció" "quando amaneció la noche" (además, en construcción quiásmica); se trata, en efecto, de una hipálage (procedimiento estilístico), pero también resultó "hipalágico" el fenómeno real producido por el ingenioso artificio de los artesanos: los fuegos artificiales iluminaron como si se hubiera hecho de día.

Es notable el pasaje sobre las corridas de toros, que comienza: "Tiene el cielo quarenta y ocho imágenes que ilustran su zaphiro, una de ellas, que, siendo imagen, es signo: es el toro, mentido robador de Europa y luciente honor del cielo, sugeto principal, por ser él la llave dorada entre los astros, con la qual abre las puertas del año" (f. 38r-v). Se ofrecen los toros, a los que por transposición gongorina Gil Ramírez llama "lunados brutos", como parte del festejo por el nacimiento del infante 
Felipe Pedro, a quien se presenta en alegoría con Neptuno (dios al que los antiguos ofrendaban toros): ${ }^{4}$

Con púrpura caliente de ferozes toros, religiosa víctima de supersticiosos gentiles, vermejearon cultos las aras húmedas de Neptuno, porque este marino numen, tan esforzado como poderoso, sujeta al imperioso dominio de su dentado ceptro, el indomable orgullo del mar, fiera christalina que, hinchando brabezas en salobres montañas, paze vidas alentando a soplos, y despertando sustos a silbos con que brama, imita tan horrible como proprio, el mugiente boato del toro (f. 39r).

De acuerdo con la alegoría marina, en épica batalla naval, ante este "nuevo Neptuno", el toro

rendirá la hundosa servis este salado monstruo, fiera que sobre los nativos bramidos con que espanta, armada ya de veleros paladiones, ya de guerreras nabes, que, puestas a son de bata1la, sangrientamente encendidas, más que a la mortal llama del azufre, al ardor vital de sus iras, alterado de estrépito marcial a los pavorosos estruendos, segunda vez horrible, o muje al formidable silvo de las balas, o brama al destemplado crujido de los cañones... (f. 39r).

Además de las obvias evocaciones y de la sintaxis y el léxico, hay que notar el influjo de Góngora en la elaboración de las imágenes, por ejemplo: a la señal, el torilero abre la puerta del coso, "y al punto, de su obscuro vientre, como de nube preñada, se abortó un rayo animado, que encendió colérico los relámpagos en sus ojos, formando en sus bramidos el trueno",

\footnotetext{
${ }^{4}$ En la Odisea se relata que Telémaco llegó a Pilo, "la sólida villa de Neles", donde "orillas del mar inmolando se hallaban los pilios / negros toros al dios peliazul que sacude la tierra" (canto III, vv. 5-6; uso la siguiente edición: Homero, Odisea, introd. M. Fernández-Galiano, trad. J. M. Pabón, Madrid, Gredos, 1982). También Heródoto narra que Cleómenes, tirano de Esparta, buscando el favor del oráculo de Delfos, "sacrificó un toro al mar" (libro VI, 76).
} 
afortunado cuadro del toro listo para la embestida. Finalmente, el arrojo del torero vence al "armado bruto", que muere "manchando el suelo con el múrice de su sangre para escrivir en tinta roja, en el trájico papel de la arena, avisos inútiles a los otros" (f. 41r).

A las corridas de toros siguieron las peleas de gallos, a los que Gil Ramírez llama "aves del sol” o "plumados duelistas”, y describe en prolongada perífrasis:

Es el gallo el ave de Phebo, porque, como sienten muchos, quando este lucido dinasta ilustra al nadir a rayos, haziéndole ruido su dorado influxo, aunque a tanta distancia, con el silencioso estruendo le despierta, para que abriendo los ojos y alentando el pico, desvelado pregonero en la intempesta noche, dé a los mortales el primer anuncio del día (f. $41 \mathrm{v})$.

Hermosa representación del amanecer gracias a la ingeniosa sinestesia del sol que "hace ruido" con su "dorado influxo" y despierta al gallo con su "silencioso estruendo" de luz. Recurrir a motivos auditivos para describir un fenómeno visual es un hallazgo: si bien lo vemos, es, en efecto, estruendosa la irrupción de la dorada luz solar cada mañana.

Ya Gerardo Diego señaló que a Góngora se debe no solo una revolución formal, sino también "el ensanche del panorama temático y la delectación en los aspectos desdeñados por baladíes y de leve sustancia" (Antología poética en honor de Góngora, 42). Las Soledades están llenas de estas “epifánicas” miniaturas en las que Góngora se deleita con tiempo, con laboriosidad de artesano y con auténtico gozo; en ellas presenta, bajo una luz totalmente nueva y reveladora, los objetos más rústicos y los seres más simples de la naturaleza, invisibles de tan cotidianos. Esta lección, este troquelar la lengua para hacerla nombrar con más precisión, sin llegar — claro está - a las alturas de Góngora, es la que Gil Ramírez lleva a la práctica en esta re- 
lación, que, si no fuera por estas pinceladas, sería un texto tan poco atractivo como un simple "diario de sucesos notables".

Volviendo al señalamiento de Antonio Carreira de que los recursos gongorinos en la prosa se usan solo para dotarla de "espesor metafórico", yo diría que no es poca razón; quitaría el solo y, en vista de los resultados, pienso que el procedimiento está plenamente justificado. Al respecto, a mediados del siglo XVII, un comentarista del cordobés escribía:

En las prosas se a visto la propia mudanza con mayor maravilla influyendo en ellas i realzándolas el estilo nuevo de Góngora; que si bien muchos que las hablan o las escriben no atienden a eso ni hazen estudio de su imitación, i aun a muchos por ventura les falta la primera noticia de que tal ombre vivió en España, como ya las formas de su estilo están enbebidas en la lengua, i de unos en otros se an dilatado, sin sentir las concibe el entendimiento, i de allí pasan a la conversación i a la pluma, obrando con secreta causalidad, como la luz i el aire de que vivimos; si en unos felizmente, $i$ en otros con infelicidad, esta diferencia débese atribuir más a la destemplanza de los ingenios que al genio de las mismas obras (Vázquez Siruela, Discurso sobre el estilo de Don Luis de Góngora, 383).

En efecto, por lo menos en Nueva España, la lengua gongorina fue como "la luz i el aire de que vivimos", pero con plena conciencia y no por "secreta causalidad". Gil Ramírez se conoce su Góngora, y lo cita textualmente en dos ocasiones. La primera para describir el adorno — todo en blanco- del carro de los panaderos: “...como esta vez México en sus calles, dando embidia a los riscos del Ida y a los peñascos de Liçeo. Nieve el pecho y armiños el pellico, pudiera cantar de ellas el Cisne de Andalucía..." (f. 50v). La segunda evocación está en la descripción del argentado carro de los plateros: para hablar de ese tan asombroso cúmulo de plata "baste por todos Góngora en su siempre gigante Poliphemo: Donde espumoso el mar siciliano / 
el pie argenta de plata al Lilibeo" (f. 57v). Sus arrobos gongorinos no son, pues, fruto de la casualidad, sino producto de una atenta y productiva lectura del poeta cordobés.

Se ha usado como el ejemplo más ilustrativo de los extremos a los que llegó el gongorismo ${ }^{5}$ la obra La elocuencia del silencio. Poema heroico, vida y martirio del gran protomártir... san Juan Nepomuceno, de Miguel de Reina Zeballos, dedicada al confesor de Felipe V, Guillermo Clarke. Se trata de un poema en diez cantos, con un total de 624 octavas, por momentos difíciles de seguir o de soportar. Menéndez Pelayo se burla de la composición diciendo que "la elocuencia del silencio", es decir, el silencio, es, precisamente, lo que hubiera convenido al poeta: "de quien poco bueno puede decirse, salvo que versificaba con robustez, dote común en los poetas de su escuela [el gongorismo], y que propendía más a lo conceptuoso que a lo culterano" (Menéndez, Historia de la poesía hispano-americana, 73 y 85$)$ :

Desciende deidad sacra, a quien da el labio mudo, elocuente, culto, que te invoca mi pluma, cuyas líneas regle sabio el índice que nudo es de tu boca. No Piérides parleras por agravio culpéis mi adoración, que sólo toca a Harpócrates, que amante reverencio, la inspiración sagrada del silencio.

(canto 1, oct. 1)

Con esta sola muestra (que es lo único que cita Menéndez Pelayo) es imposible que al lector le quede claro en qué consiste el funesto gongorismo de Reina Zeballos. La obra peca

${ }^{5}$ Entre otros: Pimentel (Historia crítica de la literatura y de las ciencias en México desde la Conquista hasta nuestros días), Menéndez Pelayo (Historia de la poesía hispano-americana, t. 1) y Alfonso Reyes (Letras de la Nueva España). 
más bien de una llaneza algo fastidiosa, y sus contados aciertos son, justamente, aquellos pasajes o versos deudores de Góngora. Y aquí no se equivoca don Marcelino: esos pasajes son más "conceptuosos" que "culteranos", esto es, se trabaja la lengua para elaborar un concepto o, simplemente, una bonita viñeta. Por ejemplo, cuando el poeta describe las altas montañas del Palatinado:

Señala el superior Palatinado, alta meta del reyno, al Occidente, que de montañas ásperas cercado, son corona y muralla de su frente: Sudetes las nombró, donde alternado respira el astro entre la flor luciente, que es tal su altura, que han vivido en ellas con presumpción de flores las estrellas.

(canto 1, oct. 19);

o el valle de Bohemia:

El valle ameno en lentas ondas mueve el cándido vellón de que, poblado, es a la vista desatada nieve, que la derrite el silvo y el cayado. Aquel de Europa robador aleve aquí dexó a su especie vinculado, que en desagravios del mentido susto, repitiesse los robos en el gusto.

(canto 1, oct. 24).

Cada una de estas dos octavas es una hermosa miniatura paisajística: las altas montañas que coronan y amurallan el valle del Palatinado, tan altas que el sol ("el astro") parece lucir entre 
flores que semejan estrellas y estrellas que semejan flores. En la segunda octava se presenta el rebaño de ovejas, tantas que con sus lentos y acompasados movimientos brindan "ondas" al valle; tantas que parecen nieve que, derretida, corre al llamado del pastor. En el valle pasta también el toro, aludido en una muy gongorina perífrasis mitológica: por el robo de aquel "mentido" toro, su especie quedó obligada (vincular en el uso forense de Góngora) a solo contemplar ("repetir los robos con el gusto") el paso del rebaño.

En otra parte, Reina Zeballos relata que el rey Wenceslao pretende convencer a san Juan Nepomuceno de que revele los secretos de la reina, pues era su confesor, "así llamando a Juan con rostro afable / (que dexa a espaldas el de sus rencores), / hypócrita volcán, sereno mueve / con blando aliento la mentida nieve" (canto 3, oct. 43). El rey esconde su furia con palabras blandas y lisonjeras (la "mentida nieve" que no corona al volcán en erupción). El poeta, entonces, para expresar con la elocuencia del caso el peligro al que se enfrenta el santo, recurre a una afortunada comparación, al estilo del poeta cordobés:

¡Oh cómo peligrara aquel canoro dulce apacible hechizo, cautelosa liga vocal, por quien lloró el Peloro estragos de Parténope engañosa! Pero el sagrado Ulises al sonoro eco perturbador, en la industriosa nave del alma sujetó oprimidos al árbol del silencio los sentidos...;

qual pyrata escamado, a quien sepulta el espumoso monstruo en sus raudales, y con la tinta que en el buche oculta obscurece los líquidos cristales, con cuya lobreguez la vista insulta 
del pezezuelo incauto, y con fatales

rasgos purpúreos dexa escrito el daño

en los negros borrones del engaño;

assí, por que a la voz suya perezca

el inocente pecho, solicita

que de Juan las orejas entorpezca

la engañosa lisonja que vomita...

(canto 3, octs. 44, 46, 47).

La primera octava alude al seductor canto de las sirenas, cifradas en una de ellas, Parténope (se arrojó al mar y las olas depositaron su cuerpo en la playa, a las faldas del monte Peloro, en Nápoles), y a la estratagema de Ulises de atarse a los mástiles para disfrutar el canto, sin arrojarse al mar. Mejor y nuevo Ulises resulta san Juan Nepomuceno (el "sagrado Ulises") que responde a los falsos halagos del rey ("sonoro eco perturbador", equivalente al canto de las sirenas) con el silencio, gracias a su grandeza de alma ("en la industria... sentidos"). Establecida la alegoría mitológica y náutica, las siguientes estrofas desarrollan la lucha del santo a la manera de un naufragio: el rey se compara con una serpiente marina ("pirata escamado"), escondida en los raudales del mar ("espumoso monstruo"), que ataca a los pececillos con la tinta que esconde en el buche y deja huellas de su mal en la púrpura disuelta en el agua; así, el rey, con "la engañosa lisonja que vomita", pretende confundir al santo. Como se ve, una comparación bastante apretada y bien trabajada.

Más adelante, Reina Zeballos apostrofa a san Juan, ponderando la fortaleza con que sufre su martirio: "Y en fin, Juan, essos duros eslabones / no os pesen, porque son, formando escalas, / plumas los grillos, las cadenas alas" (canto 5, oct. 16, nótense la bimembración y el quiasmo), y describe, con hermosas y sugerentes imágenes (y no es ironía), retomando la alegoría del naufragio empleada antes, los azotes que recibe: 
Crece la tempestad, el furor crece, como suele en el mar cuyos raudales azota el viento, $\mathrm{y}$ al herir parece que el centro le examina a los crystales, assí al caer el brazo se enfurece: a un lado y otro aparta los corales, hasta tocar, quando el ramal sepulta, escollos de marfil que el seno oculta.

(canto 5, oct. 55)

Del martirio, sale san Juan Nepomuceno robustecido, como un instrumento musical, accidentalmente maltratado al ser afinado, y luego reconstruido con mejora:

Como suele harmónico instrumento que, al compás y la regla bien trazado, la voz despide, y con su dulce acento al artífice canta lo acertado; pero la contingencia o el intento le despedaza, y únele el cuidado, de suerte que en más dulce melodía afina con su estrago la armonía.

Juzga Menéndez Pelayo que Reina Zeballos “versificaba con robustez", y digna ilustración de esta virtud son las siguientes octavas, muestra de una especie de "bucólica mexicana", en las que se describe el laborioso trabajo del indio de la meseta que, armado de su acocote, extrae el aguamiel de los próvidos magueyes: ${ }^{6}$

${ }^{6}$ Esta evocación mexicanista en una obra dedicada a ensalzar la vida de un santo bohemio (san Juan Nepomuceno es el santo patrono de Bohemia) se encuentra en medio de una digresión, también de carácter nacionalista, sobre la virgen de los Remedios, motivada, según el autor, por la descripción de la virgen de Boleslavia. 
En su fecundidad inagotable, pródigo el centro del maguey ofrece estraño mineral que al vegetable la industria ingerta, y con la planta crece: más que al pico y a la cuña, a breve sable, cabándole las manos, obedece, y de su seno cóncavo desata, en dulce néctar, líquida plata.

Y como suele abeja artificiosa, quando a la flor el labio acerca activa, que el centro chupa y labra deliciosa la miel que, sazonada, al gusto aviva; del indio assí la industria laboriosa toca el maguey y el dulce jugo liba: que al aguijón lo agudo hurta la maña, por el fácil conducto de la caña.

(canto 8, octs. 42-43)

Recordemos las viñetas antes estudiadas de Gil Ramírez. Es la misma lección del Góngora naturalista, creador de "naturalezas vivas". En los tres poetas, el español y los novohispanos, estos cuadros son realistas; las insólitas comparaciones, su trabajada expresión no "des-realizan" la escena, al contrario, la detallan y precisan. ${ }^{7}$

\footnotetext{
${ }^{7}$ José María Vigil pensaba que los poetas gongorinos del siglo XVII, con estos circunloquios, escamoteaban el "significado directo" de las palabras y lo sustituían con traslaticios arbitrarios (Reseña histórica de la literatura mexicana, 333). Sin embargo, como ha demostrado Nadine Ly, con este proceder perifrástico lo que se busca, precisamente, es el fenómeno contrario, abolir la arbitrariedad del signo: la expresión se acerca (y nos acerca) a la realidad, revelando aspectos inauditos (por no vistos, no por irreales): "la expresión indirecta y las perífrasis, las llamadas metáforas y la sintaxis, hiperbática o anacolútica, no son, en la poesía de Góngora sino la manera más directa de rendir lo intuido..." ("Propiedad lingüística y verdad de las cosas: 'deleyte de la palabra, deleyte de la cosa'”, 163). Así, por ejemplo, Antonio Carreira subraya la inspiración netamente realista de la escena en la que Polifemo, espantando las cabras a pedradas, sin querer, provoca la separación y huida de Acis
} 
Junto con Reina Zeballos, se ha considerado a Francisco Ruiz de León ejemplo del gongorismo novohispano del siglo XVIII: "Francisco Ruiz de León versifica La conquista de México de Solís en su Hernandia; y aunque tal poema suele considerarse como la mejor obra del género, entiendo que el poeta es más apreciado por su obra gongorino-religiosa, Mirra dulce, publicada posteriormente en Bogotá" (Reyes, Letras de la Nueva España, 99). Menéndez Pelayo considera que el autor perteneció "a una época literaria completamente agotada y fenecida", que se trata del "último poeta de su escuela" [i.e. gongorismo] (Historia de la poesía hispanoamericana, 81). A diferencia de otros estudiosos, para el santanderino, mejor que la Hernandia es su "rarísimo poemita de 333 décimas, muy devotas y muy conceptuosas, que lleva el título de Mirra dulce para aliento de pecadores". En verdad, no sé qué vio el crítico santanderino en Mirra dulce; se trata de una composición rimada (no alcanza ni la categoría de "poemita"), formada por 330 décimas (no 333) apenas soportables, de factura menos que mediana, insulsas hasta el fastidio. Así, pues, aquí me limitaré a comentar los supuestos rasgos gongorinos de la Hernandia. ${ }^{8}$ Se trata de un extenso poema épico, en octavas,

y Galatea: a la manera que "un campesino que, ojeando las aves de su sembrado, ahuyenta sin querer una pareja de liebres oculta en un surco ("tal redimiendo de importunas aves / incauto meseguero sus sembrados, / de liebres dirimió copia así amiga / que vario sexo unió y un surco abriga", vv. 477-480). Cosas como estas no pudo Góngora sacarlas de los libros, sino de la observación minuciosa de la realidad" ("La especificidad del lenguaje gongorino", 104).

${ }^{8}$ Al parecer, no es Ruiz de León el autor de la Hernandia: "Según demuestra el P. Eugenio de Uriarte, Catálogo razonado de obras anónimas u seudónimas de autores de la Compañia de Jesús pertenecientes a la antigua Asistencia española, tomo 3, Madrid, 1906, 220-221, el verdadero autor es el jesuita Juan de Buedo y Girón" (Antonio Alatorre, Sor Juana a través de los siglos, t. 2, 597). Curiosamente, en los preliminares de la edición de 1755 encontramos un "Romance heroyco en elogio de don Francisco Ruiz de León" y unas "Octavas jocoserias al mismo assumpto" de Buedo y Girón; el final del romance es todo un elogio del héroe (Hernán Cortés), del poema y del autor, de tono tan exaltado que resulta difícil creer que Buedo y Girón hubiera podido auto-alabarse de esa manera, si es él, en efecto, el autor. No he 
según la mejor tradición épica, con buenos y malos momentos (debido a su extensión), al que no creo que pueda calificarse de "gongorino" ("no era la técnica culterana instrumento apropiado a la relación dilatada" [Diego, Antología poética en honor de Góngora, 50]), a pesar de que desde Beristáin se le viene achacando este "defecto": "Los defectos que se encuentran en este poema deben atribuirse al mal gusto de la época, y no a falta de ingenio ni de conocimiento del autor" (Biblioteca hispanoamericana septentrional, s.v.). En general, podría decirse que ni la sintaxis, ni el léxico, ni las imágenes son producto de la lección gongorina, pero sí hay varios pasajes en que el autor ostenta con gala sus modos gongorinos (conceptos, fórmulas, algo de vocabulario, comparaciones). Hay que destacar que, curiosamente, son estos pasajes los más afortunados: resaltan como oasis en medio de su prosaísmo y llaneza "rimados", por momentos aún más plúmbeos que los gongorinos arrebatos del siglo anterior. La lección de Góngora destaca, por ejemplo, en la imagen de un peñasco que se levanta en medio del mar cual "verde garza":

Aún sin ver apagado su corage, levan las anclas, toman la derrota, hasta que el passo corta del parage un peñol que es del mar verde garzota: promontorio sobervio, que su ultrage venga en el golfo, quando más le azota; como que a embates fuertes solicita cobrar lo que usurpado aquél le quita.

(canto 1, oct. 53);

encontrado más noticias al respecto. En los preliminares de Mirra dulce, el editor, Diego Terán, y el censor, Pedro Fernández de Madrid, dicen, con sospechosa insistencia, que se trata del mismo autor de la Hernandia. Quede, por ahora, el misterio, pero sí es un hecho que cuesta creer que Ruiz de León sea el autor de dos textos tan dispares en calidad y en oficio. 
o en la siguiente descripción del temporal sufrido por Hernán Cortés en su viaje de Cuba a Cozumel:

Al Atlántico embiste proceloso a trasegar en sus ocultos senos de Amphitrite el palacio cavernoso, donde ovas lame, si fulmina truenos. Éste, encrespando rizos espumoso, diáfanos montes mueve de ira llenos, y por tragarle, quando lo sufoca, de cristal abre la cerúlea boca.

Bolcán de plata que, a la ardiente llama con que el Bóreas el vientre le alimenta, preñado del ardor en que le inflama, por bocas mil intrépido rebienta: quanta concha, coral, ova y escama guardó en sus lamas, al Impýreo avienta, siendo la nieve que en sus ondas riza de espuma cana cándida ceniza.

No sólo ya las gotas y corales al uracán colérico le arroja, al ver que desgajado en sus raudales, su cerviz trunca, si su espada moja: con erizadas picas de cristales, las nubes y los vientos desaloja, y quando aguas con aguas se conmueven, llueven los cielos y los mares llueven...

Assí turbado el seno mexicano, en undoso sepulcro sumergido dexar presume del valor hispano el velamen, dos vezes oprimido. Ya deshecha la armada mira en vano Cortés, su zelo, su fervor perdido, 
y entre syrtes, baybenes y assechanzas

anegadas en flor sus esperanzas.

Como suele veloz pyrata errante, calzando velas de ligera pluma, escalar el zenit tras la volante garza, y baxarse con violencia suma, tal en las ondas tanta naufragante popa, con alas de salobre espuma, mide, impelida, sin timón ni entenas, del cielo signos, de la mar arenas.

(canto 1, oct. 96-101)

Notemos el léxico (ovas, cerúleo, espuma cana, undoso sepulcro), la eficaz perífrasis mitológica del palacio cavernoso de Anfitrite (por la profundidad del mar), la viveza de las imágenes que pintan la furia del océano: en la primera octava, el océano, "encrespando rizos espumoso", embiste las naves de Cortés con iracundos montes de agua (diáfanos), las sofoca y se las traga abriendo "de cristal cerúlea boca"; en la segunda, el Atlántico se presenta cual "volcán de plata", inflamado de ardor por el viento, revienta, lanzando al cielo conchas, corales, tesoros a los que, a su vez, ofrece "cándido" sepulcro en su crispada espuma. El mismo océano provoca la tormenta que se desata en "erizadas picas de cristales"; todo es confusión, bien expresada en el último verso de la tercera octava con la reiteración del verbo en el quiasmo: "llueven los cielos y los mares llueven" (por este doble "hundimiento", más adelante dice el poeta que el velamen fue "dos veces oprimido"). En la última octava de este pasaje, el autor elabora una comparación original: como el ave de rapiña vuela hacia lo más alto para luego descender velozmente sobre la garza, así las destrozadas naves (sinécdoque por Cortés y sus hombres) lanzan su mirada al cielo, inquiriendo lo que les depara, y hacia la costa, anhelando tierra firme. La relación con el ave de rapiña pone en primer 
plano no solo la velocidad con que se mueve la mirada, sino la avidez, la ansiosa angustia. Tras el temporal, una de las naves de Cortés "ruina es del Noto, si de la agua astilla" y los sobrevivientes "parabienes se dan, y discursivos / no se ven muertos y se dudan vivos".

Véase también esta representación de la Esperanza (con la evocación gongorina del cuarto verso):

La mentida deydad que a los humanos

embelesados tiene los sentidos, cuyos anuncios dulcemente vanos, o mal, o tarde, o nunca son cumplidos; la que brindando bienes a dos manos da al corazón mil sustos repetidos, y al descubrirse muestra su figura: cerca fealdad y lexos hermosura.

(canto 2, oct. 1);

o, como antes lo hizo Gil Ramírez, la representación de la cochinilla, insecto del que los indios obtenían la púrpura:

Del múrice la concha soberana ya no hace falta, quando en su retiro Tlaxcala engendra la coccinea grana, a ser afrenta del carmín de Tyro: ascua de oro, coral de filigrana, exhalación de sangre, cuyo gyro, empapando al vellón, a quien alhaga, la vista enciende con lo que la apaga. (canto 3, oct. 69);

o bien esta curiosa octava describiendo a un guerrero de Moctezuma: 
Ni de la Trinacria promontorio altivo, ni de Quito peruano Mongivelo, gargantas por adonde el Lethe esquivo con avenidas de humo empaña al cielo, compiten al membrudo jayán vivo, monte animado, pues de cielo y suelo no sólo iguales las distancias toca, todo lo ahuma el aliento de su boca.

(canto 6, oct. 32);

imposible no pensar en la horrorosa hermosura de Polifemo. Veamos también el final del relato de la victoria de las naves de Cortés sobre las de Cuahutémoc en el lago de Texcoco:

No assí en la azul campaña de Amphitrite, alguna vez cercada de lunadas lonas, maltés galera a tal embite rompió sangrienta furias represadas, quando el pagano, sin hallar desquite a su locura, lamentó anegadas en undoso sepulcro, con espanto, quillas que asombro dieron a Lepantho.

(canto 12, oct. 29);

finalmente esta dilatada perífrasis temporal para hablar de la estación primaveral:

Gozaba el año su estación florida, o ya estival, según la considera chronográpho patricio a la medida que en su eclíptica Fevo reverbera, quando, rota la yema entumecida, buelve rubí lo que esmeraldas era, 
y blancas sienes Amalthea corona

del cultivo fragrante de Pomona.

En el purpúreo tiempo delicioso,

galán Narciso de argentada plata,

Adonis tierno del boscage umbroso,

que a uno viste y en otra se retrata:

en el de Ceres Benjamín gracioso,

en la flor de los meses, en la grata

era de Venus, de Cibele ensayo,

en lo mejor, en primavera, en mayo.

(canto 12, oct. 109)

Es notable que a estas alturas del siglo XVIII la lección gongorina permita a poetas más bien menores cosechar frutos más o menos bien sazonados: "Poetas de dotes no extraordinarias pudieron, gracias a esta lección [la de Góngora], aprender secretos de autocrítica, y trabajar el idioma humilde, pacientemente, en un modo de estilo colectivo, de estilo arquitectónico en que basta un discreto gusto para conseguir bellezas objetivas e indudables" (Diego, Antología poética en honor de Góngora, 57).

Junto a estos pasajes, que se podrían considerar de "factura gongorina", salpicados por toda la obra hay uno que otro giro deudor del cordobés: "pues quando sobre sí saca la cara, / o mal, o tarde, o nunca se repara" (canto 6, oct. 50, vv. 7-8), "a discernir no acierta si es en suma / golfo de mármol, o Babel de espuma" (canto 6, oct. 69, vv. 7-8), "las centellas, que son en gyro leve / pájaros de cristal, aves de nieve" (canto 8, oct. 13, vv. 7-8), "Desprendiendo botones quedó el cielo / jardín turquí bordado de diamantes, / mostrando al mundo, quando lo retrata, / en campos de zaphir flores de plata" (canto 8, oct. 14, vv. 5-8), $\mathrm{y}$, para terminar, véase el remate de la siguiente octava:

Mundo inconstante, ¿dónde tu ventura se hallará y de tus bienes la firmeza, 
si en el breve ademán de tu locura

todo acaba en el punto que se empieza?

Necedad será creer lo que no dura, si fausto, honor, soberanía, grandeza, conviertes, a un impulso de tu azada, en tierra, en lodo, en polvo, en humo, en nada.

(canto 10 , oct. 48$)^{9}$

En conclusión: hay que destacar el descubrimiento del Góngora de las pequeñas cosas, hecho por nuestros gongorinos del siglo XVIII. Gil Ramírez, Reina Zeballos y quien fuera el autor de la Hernandia fueron capaces de encontrar y, siguiendo al maestro, expresar la maravilla y belleza de la cochinilla, del aguamiel, de los gallos, de los toros. No es esta la lección más "espectacular" del poeta cordobés, al contrario, es la más íntima y compleja:10 "Así, lo más sorprendente del poema [de las Soledades] resulta ser la inextricable mezcla de realidad e idealidad, de amor a lo humilde, expresado en conceptos complejos, lo que constituye una intencionalidad a la vez ética y estética única en su tiempo" (Carreira, Gongoremas, 11). Los tres poetas analizados tuvieron la sensibilidad para aquilatar esa singularidad gongorina y la lucidez de seguir al maestro por

${ }^{9}$ Hay que resaltar, además, que en todos los casos los giros gongorinos se usan para rematar las octavas, esto es, como recurso para lograr mayor expresividad y contundencia.

${ }^{10}$ En el siglo XVII el único antecedente de esta práctica es sor Juana; desde otra perspectiva, lo difícil que es llegar al conocimiento verdadero, en su Primero sueño se detiene en dos objetos de la realidad cotidiana: una fuente (vv. 712-729), descrita por medio de una perífrasis basada en una cifrada noticia mitológica ("enigmas mitológicos", las llama María Rosa Lida de Malkiel, La tradición clásica en España) y la rosa (vv. 730-756): "quien de la breve flor aun no sabía / por qué ebúrnea figura / circunscribe su frágil hermosura; / mixtos, por qué, colores, / confundiendo la grana en los albores, / fragante le son gala; / ámbares por qué exhala, / y el leve, si más bello / ropaje al viento explica, / que en una y otra fresca multiplica / hoja, formando pompa escarolada / de dorados perfiles cairelada, / que, roto del capillo el blanco sello, / de dulce herida de la cipria diosa / los despojos ostenta jactanciosa..." (Sor Juana, Obras completas, t. 1, 527-528). 
este camino, no por el más hollado de ciertos procedimientos estilísticos. Hay que reconocer que, en verdad, sus miniaturas muestran una provechosa asimilación de esa sui generis lección del poeta cordobés. Escribe Joaquín Roses que "para encontrar un verdadero gongorista habría que hallar una analogía en la actitud renovadora, en la intención transformadora, en el ejercicio innovador, no una copia de los resultados del mismo" ("La alhaja en el estiércol: claves geográficas y estéticas de la poesía virreinal”, 421). Creo que, con sus limitaciones (se trata de ingenios menores), los tres autores aquí presentados tienen esa "intención renovadora, transformadora"; los tres buscan ese "ejercicio innovador", sin recurrir a la simple copia de los usos del modelo; poseen, en fin, la jerarquía para ser considerados seguidores, y no del montón, de Góngora.

\section{REFERENCIAS}

Alatorre, Antonio, Sor Juana a través de los siglos, 1668-1910, México, El Colegio de México-El Colegio Nacional-Universidad Nacional Autónoma de México, 2007.

BERISTÁIN, José Mariano, Biblioteca hispanoamericana septentrional, ed. facs., México, Universidad del Claustro de Sor JuanaUniversidad Nacional Autónoma de México, 1980.

CARreira, Antonio, "Góngora y el canon poético", en El canon poético en el siglo XVII, B. López Bueno (dir.), Sevilla, Grupo PASOUniversidad de Sevilla, 2010.

CArreira, Antonio, Gongoremas, Barcelona, Península, 1998.

CARreira, Antonio, "La especificidad del lenguaje gongorino", $\mathrm{Bu}$ lletin Hispanique, 112, 2010, 89-112.

CARreira, Antonio, "Pros y contras de la influencia gongorina en el Triunfo parténico (1683) de Sigüenza y Góngora", en Homenaje a Henri Guerreiro. La hagiografia entre historia y literatura en la España de la Edad Media y Siglo de Oro, M. Vitse (ed.), Pamplona-Tolouse, 2005, 347-364. 
Cruz, sor Juana Inés de la, Obras completas, t. 1: Lírica personal, ed., introd. y notas de A. Alatorre, México, Fondo de Cultura Económica, 2009.

Diego, Gerardo, Antología poética en honor de Góngora, Madrid, Revista de Occidente, 1927.

Gil Ramírez, José, Esfera mexicana, México, Viuda de Miguel de Ribera, 1714.

Góngora y Argote, Luis de, Antología poética, A. Carreira (ed.), Barcelona, Crítica, 2009.

Góngora y Argote, Luis de, Soledades, R. Jammes (ed.), Madrid, Castalia, 1994.

GRANADA, fray Luis de, Introducción al Símbolo de la Fe, J. M. Balcells (ed.), Madrid, Cátedra, 1989.

Heródoto, Historia, ed. y trad. M. Balasch, Madrid, Cátedra, 1999.

Homero, Odisea, introd. M. Fernández-Galiano, trad. J. M. Pabón, Madrid, Gredos, 1982.

LidA, María Rosa, La tradición clásica en España, Barcelona, Ariel, 1975.

Ly, Nadine, "Propiedad lingüística y verdad de las cosas: 'deleyte de la palabra, deleyte de la cosa' (A propósito del anti-barroquismo de Machado)", en Góngora hoy, I-II-III, J. Roses (ed.), Córdoba, Diputación de Córdoba, 2002, 145-177.

Menéndez Pelayo, Marcelino, Historia de la poesía hispanoamericana. T. 1, Edición nacional de las obras completas de Menéndez Pelayo. Vol. 27, Madrid, Consejo Superior de Investigaciones Científicas, 1948. Edición digital en: <http://www.cervantesvirtual.com/obra/historia-de-la-poesia-hispanoamericana-t-1—0/> [fecha de consulta: octubre, 2011].

Pimentel, Francisco, Historia crítica de la literatura y de las ciencias en México desde la Conquista hasta nuestros días, México, Librería de la Enseñanza, 1885.

Plinio, Historia natural, trad. y notas E. del Barrio Sanz, I. García Arribas, A. M. Moire Casas et al., Madrid, Gredos, 2003.

Reina Zeballos, Miguel de, La elocuencia del silencio. Poema heroico, vida y martirio del gran protomártir... san Juan Nepomuceno, Madrid, Miguel de Peralta, Madrid, 1738. 
Reyes, Alfonso, Letras de la Nueva España [1946], México, Fondo de Cultura Económica, 1986.

Roses, Joaquín, "La alhaja en el estiércol: claves geográficas y estéticas de la poesía virreinal", en Literatura y territorio. Hacia una geografía de la creación literaria en los Siglos de Oro, A. Sánchez Robayna (ed.), Las Palmas de Gran Canaria, Academia Canaria de la Historia, 2010, 407-443.

Ruiz de León, Francisco, Hernandia, Madrid, Viuda de Manuel Fernández, 1755.

Ruiz de León, Francisco, Mirra dulce para aliento de pecadores, Santafé de Bogotá, Antonio Espinosa de los Monteros, 1791.

SigüEnza y Góngora, Carlos de, Triunfo parténico [1683], J. Rojas Garcidueñas (ed.), México, Xóchitl, 1945.

Tenorio, Martha Lilia, Poesía novohispana. Antología, t. 2, México, El Colegio de México-Fundación para las Letras Mexicanas, 2010.

Vázquez Siruela, Martín, Discurso sobre el estilo de don Luis de Góngora. Carácter legítimo de la poética, en don Luis de Góngora y Argote. Biografía y estudio crítico, Miguel Artigas, Madrid, tipografía de la "Revista de Archivos", 1925, 380-394.

VIgIL, José María, Reseña histórica de la literatura mexicana, México, s.p.i., 1909. 